\title{
Peningkatan Sistem Imun Keluarga Di Era Pandemi Covid-19
}

\author{
Sri Nabawiyati Nurul Makiyah ${ }^{1 *}$, Nurvita Risdiana ${ }^{2}$ \\ ${ }^{1,2}$ Program Studi Pendidikan Dokter, Fakultas Kedokteran dan Ilmu Kesehatan Universitas \\ Muhammadiyah Yogyakarta \\ *Email: nurul.makiyah@umy.ac.id
}

\begin{abstract}
Background: The Covid-19 pandemic has triggered public awareness to stay at home, so that community gathering activities are canceled, including routine community gymnastics activities. The aim of its community service activity is to increase public awareness of the Salakan hamlet regarding health protocols by increasing the family's immune system and physical activity during the Covid-19 pandemic for women in the Salakan, Trihanggo, Gamping, Sleman. Methods: this community services activity used lectures on improving the family's immune system and appropriate physical activity in the era of the Covid-19 pandemic. The lectures and discussions both offline and online course. It is done offline at the residents' meeting building on March 1, 2021 with 20 Health Cadres whose members are the same as the Salakan women's gymnastics board. MS Teams meeting online on Sunday, February 7, 2021. Evaluation is done by measuring the level of knowledge of participants about the immune system and the level of knowledge about physical activity is done through posttest with google form. Results: this community service activity showed that the participants were very enthusiastic and there was a warm discussion about the topic given. Post-test results showed that the level of knowledge of participants about the immune system was $80.00 \pm 10.34$ (very good) and the level of knowledge about physical activity was $76.25 \pm 15.00$ (good). Conclusion: the women of the Gymnastics group after being given socialization about the immune system and physical activity experienced an increase in knowledge about how to improve the immune system and what physical activities were good to do during the Covid-19 pandemic.
\end{abstract}

Keywords: women of the salakan gymnastics group, immune system, physical activity, covid-19 pandemi;

\section{PENDAHULUAN}

Virus Corona adalah virus yang menyerang saluran pernafasan. Tanda dan gejala yang muncul adalah gangguan pernafasan akut seperti demam, batuk dan sesak napas. Pada kasus yang berat menyebabkan pneumonia, sindrom pernafasan akut, gagal ginjal dan bahkan kematian (PDPI, 2020). Partisipasi dan dukungan dari warga masyarakat untuk tetap tinggal di rumah (Crosbie \& Moore, 2004) dan menjaga kesehatan agar tetap sehat dan produktif sangat diperlukan guna mendukung program pemerintah untuk memutus rantai penularan virus Corona yang dikenal sebagai Covid-19.

Selain dengan menjalankan protokol kesehatan yang ketat, maka tubuh kita perlu dipersenjatai dengan sistem imun yang kuat. Oleh karena daya tahan tubuh kita sangat tergantung dengan sistem imun. Apabila tubuh kita memiliki system imun yang baik, maka daya tahan tubuh yang tinggi sehingga mampu memerangi virus Corona. Jadi menjaga daya tahan tubuh sangat penting untuk dilakukan agar terhindar dari infeksi Covid-19.

Tubuh manusia memiliki sistem imun alamiah atau imunitas bawaan, meskipun demikian, tubuh kita juga memerlukan imunitas yang didapat untuk dapat memperkuat serta menjaga sistem imun serta melawan benda asing yang berupaya masuk ke dalam tubuh (Makiyah, 2021). Oleh karena itu pengetahuan tentang peningkatan sistem imun bagi keluarga di masa pandemi Covid-19 ini sangat penting diberikan kepada Ibu-Ibu sebagai garda terdepan dalam keluarganya.

Ibu-ibu kelompok senam di dusun Salakan, Trihanggo, Gamping Sleman rutin menyelenggarakan senam seminggu 2x, akan tetapi di masa pandemi Covid-19 ini 
menjadi terkendala untuk melakukan aktivitas fisik secara rutin yaitu senam yang telah berjalan selama 3 tahun terakhir. Oleh karena keterbatasan waktu dan pengetahuan dari Ibu-Ibu kelompok senam ini, sehingga belum memiliki pengetahuan tentang aktivitas fisik yang bisa dilakukan di dalam rumah masing-masing, tanpa harus berkerumun sehingga aktifitas fisik bisa tetap dijalankan.

Tujuan kegiatan abdimas ini adalah meningkatkan kesadaran masyarakat dusun Salakan mengenai peningkatan sistem imun keluarga dan aktivitas fisik selama pandemi Covid-19 pada Ibu-Ibu kelompok senam dusun Salakan, Trihanggo, Gamping, Sleman.

\section{TINJAUAN PUSTAKA}

Keluarga adalah lingkungan terkecil dari masyarakat yang terdiri dari ayah, ibu, dan anak. Ketiga komponen keluarga tersebut memiliki peran dan tanggung jawab masing-masing. Ayah merupakan kepala keluarga dan ibu memiliki peran sebagai istri bagi suami dan juga ibu bagi anak-anaknya (Kardini, 2020). Keluarga merupakan bagian yang tak terpisahkan dalam kehidupan. Keluarga menjadi tempat pertama seseorang memulai kehidupannya. Keluarga membentuk suatu hubungan yang sangat erat antara ayah, ibu, dan anak.

Hubungan tersebut terjadi antar anggota keluarga yang saling berinteraksi. Keluarga sebagai institusi sosial terkecil yang merupakan fondasi dan investasi awal untuk membangun kehidupan sosial dan kehidupan bermasyarakat secara luas menjadi lebih baik karena internalisasi nilai-nilai dan norma-norma sosial jauh lebih efektif dilakukan (Zahrok \& Suarmini, 2018). Keluarga merupakan forum pendidikan yang pertama dan utama dalam sejarah hidup anak yang menjadi dasar penting dalam pembentukan karakter manusia itu sendiri. Untuk menciptakan karakter yang kuat dan jiwa baik pada anak didalam keluarga, diperlukan terciptanya suasana keluarga yang harmonis dan dinamis, hal tersebut dapat tercipta jika terbangun koordinasi dan komunikasi dua arah yang kuat antara orang tua dan anak (Hyoscyamina, 2011).

Ibu merupakan sosok yang tidak bisa dihilangkan dalam sebuah keluarga. Peran aktif orang tua merupakan sebuah usaha yang secara langsung dalam memberikan sosialisasi terhadap anak dan juga menciptakan lingkungan. Rumah sebagai lingkungan sosial pertama yang dijumpai oleh anak (Zahrok \& Suarmini, 2018). Sepanjang sejarah peradapan manusia, besarnya peranan perempuan diawali dengan melahirkan, merawat, serta membesarkan generasi-generasi penerus bangsa yang unggul, semangat, aktif, kreatif, bermoral kemanusiaan, dan penuh inisiatif. Peran ibu sangat besar dalam mewujudkan kebahagiaan dan keutuhan keluarga (Pudjiwati, 1993).

Ibu sangat berperan dalam menjaga sistem imun tubuh bagi keluarganya, setiap keluarga perlu membangun sistem imun yang baik, sehingga kesehatan anggota keluarga dapat terjaga dan tidak mudah terserang penyakit. Hal ini penting dilakukan saat ini, mengingat virus corona masih mengancam kesehatan masyarakat. Kebijakan pemerintah untuk melakukan isolasi mandiri di rumah saja mengharuskan Ibu-ibu sebagai garda terdepan dalam rumah tangga untuk melakukan jurus jitu agar daya tahan tubuh anggota keluarganya tetap prima yaitu dengan cara 1) menerapkan pola makan teratur dan gizi seimbang dengan memperbanyak asupan sayur dan buah serta mengurangi makanan siap saji dan goreng-gorengan, 2) menerapkan pola hidup bersih dan sehat dalam kehidupan sehari-hari yaitu dengan rajin cuci tangan dan memakai masker saat beraktivitas di luar rumah, 3) istirahat yang cukup dan berkualitas, 4) rajin berjemur di pagi hari, 5) berpikiran positif dengan mengelola stres dengan baik, 6) menghindari minum-minuman beralkohol dan merokok, serta 7) tetap beraktifitas fisik 
(olah raga) minimal 30 menit minimal 3 kali seminggu (Adhi, 2020; Mustofa \& Suhartatik, 2020).

Latihan olahraga memiliki efek terhadap sistem pertahanan tubuh. Secara umum, olahraga mempromosikan resirkulasi sel-sel yang berperan dalam sistem pertahanan tubuh, dan memediasi keadaan antiinflamasi dan antioksidan melalui berbagai mekanisme. Efek yang diinduksi oleh olahraga ini dapat membantu melawan perkembangan penyakit metabolik kronis dan juga menyebabkan massa lemak tubuh berkurang (Nieman \& Wentz, 2019).

\section{DESAIN PENELITIAN}

Pengabdian masyarakat ini dilaksanakan bekerja sama dengan Ibu-Ibu Kelompok Senam dusun Salakan, Trihanggo, Gamping, Sleman dan dilaksanakan pada bulan Februari- Maret tahun 2021. Pada pertemuan pertama dilakukan sosialisasi tentang bagaimana meningkatkan sistem imun keluarga di era pandemi Covid-19. Pertemuan ke-2 dengan materi tentang aktivitas fisik yang bisa dilakukan di era pandemi Covid-19. Kegiatan ini dilakukan secara luring di Gedung Pertemuan warga dengan protokol Kesehatan dan dilakukan evaluasi tingkat pengetahuan tentang sistem imun dan aktivitas fisik setelah kegiatan dengan menggunakan form google (postes).

Metode yang digunakan dalam kegiatan pengabdian masyarakat ini yaitu dengan ceramah dan diskusi tentang masalah kesehatan khususnya peningkatan sistem imun keluarga dan aktivitas fisik yang bisa dilakukan di masa pandemi Covid-19. Sasaran pengabdian masyarakat ini adalah kelompok senam Ibu-ibu dusun Salakan, Trihanggo, Gamping Sleman.

Adapun tahapan kegiatan pengabdian masyarakat ini adalah 1) pengurusan ijin pelaksanaan kegiatan abdimas, 2) sosialisasi tentang peningkatan sistem imun keluarga di era pandemi Covid-19 dengan metode ceramah yang interaktif dan diskusi, 3) sosialisasi tentang aktivitas fisik yang bisa dilakukan di masa pandemi Covid-19 dengan metode ceramah yang interaktif dan diskusi, 4) Evaluasi keberhasilan kegiatan dengan mengisi kuesioner pada google form dan pengisian data diri peserta.

Data berupa karakteristik responden dan skor tingkat pengetahuan tentang sistem imun dan aktivitas fisik di era pandemi Covid-19 dilakukan analisis data secara deskriptif.

\section{HASIL PENELITIAN}

Kegiatan pengabdian masyarakat ini telah terlaksana dengan baik dan diikuti oleh 20 orang ibu-ibu anggota kelompok senam dusun Salakan, Trihanggo, Gamping Sleman yang juga merangkap sebagai kader Kesehatan. Adapun karakteristik responden dapat dilihat pada Tabel 1 .

Tabel 1. Karakteristik Responden

\begin{tabular}{lcc}
\multicolumn{1}{c}{ Karakteristik } & Jumlah & Persentase (\%) \\
\hline $\begin{array}{l}\text { Jenis Kelamin } \\
\quad \text { Wanita }\end{array}$ & 20 & 100 \\
Usia (Depkes, 2009) & & \\
$\quad$ Remaja akhir (17-25) th & 11 & 55 \\
$\quad$ Dewasa (26-45) th & 8 & 40 \\
Lansia (46-64) th & 1 & 5
\end{tabular}

\section{Pendidikan}




\begin{tabular}{lcc}
\hline \multicolumn{1}{c}{ Karakteristik } & Jumlah & Persentase (\%) \\
\hline Dasar & 1 & 5 \\
Menengah (SMP/SMA) & 11 & 55 \\
Tinggi (Diploma/S1) & 8 & 40 \\
Aktivitas & 3 & 15 \\
$\quad$ Tidak Bekerja & 17 & 85 \\
Bekerja & & \\
Jenis Pekerjaan & 4 & 20 \\
$\quad$ Guru & 1 & 5 \\
ASN & 8 & 40 \\
Swasta & 7 & 35 \\
$\quad$ Wiraswasta & & \\
Pendapatan (UMR Sleman, 2021) & 14 & 70 \\
$\quad$ < Rp. 2.004.000,- & 4 & 20 \\
Rp. 2.004.000,- - Rp. 4.008.000,- & 1 & 5 \\
Rp. 4.008.000,- - Rp. 6.012.000,- & 1 & 5 \\
$\quad$ Rp. 6.012.000,- & & \\
Status Pernikahan & 14 & 70 \\
Belum Menikah & 6 & 30 \\
Menikah
\end{tabular}

Berdasarkan tabel 1 yang berisi penjelasan tentang karakteristik responden dalam kegiatan abdimas ini. Responden dalam kegiatan abdimas ada 35 orang tetapi yang berhasil mengisi kuesioner dari google form ini sebanyak 20 orang. Responden ini semuanya wanita sebanyak 20 orang (100\%) dengan usia didominasi oleh remaja akhir (17-25 tahun) sebesar 55\%, diikuti usia dewasa (26-45 tahun) dengan persentase $40 \%$ dan usia lansia (46-64 tahun) sebesar 5\% berdasarkan kriteria usia dari Depkes RI (2009). Adapun pendidikan yang terbanyak adalah pendidikan menengah (SMP/SMA) sebesar 55\%, diikuti pendidikan tinggi (Diploma/S1) sebesar $40 \%$ dan pendidikan dasar dengan persentase $5 \%$.

Selanjutnya aktivitas responden adalah bekerja sebesar $85 \%$ dan yang tidak bekerja sebesar $15 \%$ dengan jenis pekerjaan terbanyak sebagai pegawai swasta dengan persentase $40 \%$, diikuti wiraswasta sebesar 35\%, guru sebesar $20 \%$ dan ASN hanya $5 \%$. Adapun pendapatan responden paling banyak masih di bawah UMR sebesar $70 \%$, diikuti 1-2 kali lipat UMR sebesar 20\%, responden dengan 2-3 kali lipat UMR sebanyak $5 \%$ dan responden yang memiliki pendapatan lebih dari 3 kali lipat dengan persentase $5 \%$. Untuk status pernikahan responden paling banyak adalah belum menikah dengan persentase $70 \%$ dan yang telah menikah sebanyak $30 \%$.

Adapun materi yang diberikan dalam kegiatan pengabdian masyarakat ini adalah tentang dasar-dasar sistem imun, sistem imun alamiah yang ada dalam tubuh kita, tips agar tetap sehat di masa pandemi, bagaimana meningkatkan sistem imun di masa pandemi, makanan yang sehat untuk meningkatkan sistem imun, bagaimana mengelola stres di masa pandemi.

Adapun materi yang diberikan pada aktivitas fisik bagi Ibu-Ibu di masa pandemi Covid ini adalah tentang perbedaan antara gerak badan dan aktivitas fisik, aktivitas fisik apa yang aman bagi Ibu-Ibu. Aktivitas latihan fisik ringan lebih bermanfaat pada fungsi imunitas bila dibanding hanya melakukan aktivitas berupa duduk/tidak melakukan 
kegiatan apapun. Kekebalan tubuh dapat dengan mudah ditingkatkan dengan melakukan latihan fisik/olahraga juga istirahat serta tidur cukup.

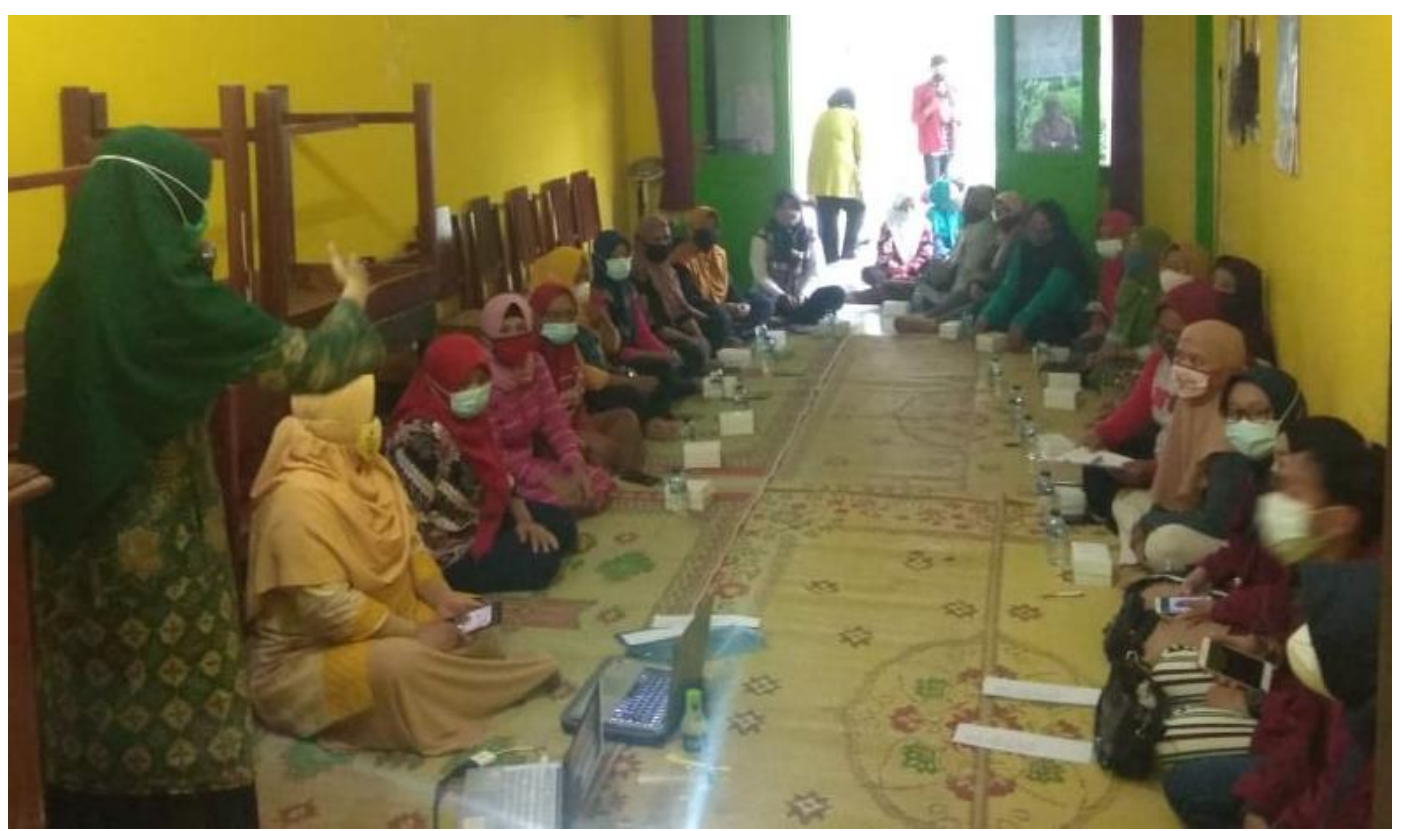

Gambar 1. Pertemuan dengan kader Kesehatan dan anggota senam Ibu-ibu dalam rangka edukasi peningkatan sistem imun di era pandemi Covid-19 pada hari Jum'at 12 Februari 2021 di Gedung pertemuan dusun Salakan, Trihanggo, Gamping, Sleman.

Pada kegiatan pengabdian masyarakat ini juga dilakukan pengambilan data postes tentang tingkat pengetahuan Ibu-Ibu kelompok senam tentang peningkatan sistem imun keluarga dan aktivitas fisik seperti terlihat pada Tabel 2. Hasil postes menunjukkan bahwa pengetahuan remaja tentang peningkatan sistem imun keluarga dengan skor ratarata $80,00 \pm 10,34$ dengan kategori sangat baik, skor pengetahuan remaja tentang aktivitas fisik yang baik dengan rata-rata 76,25 \pm 15,00 dengan kategori baik.

Tabel 2. Hasil penilaian pengetahuan responden tentang sistem imun dan aktivitas fisik

\begin{tabular}{ccc}
\hline Variabel yang dinilai & Skor & Keterangan \\
\hline Sistem Imun Keluarga & $80,00 \pm 10,34$ & Sangat baik \\
Aktivitas Fisik & $76,25 \pm 15,00$ & Baik \\
\hline
\end{tabular}

\section{PEMBAHASAN}

Menurut Mustofa dan Suhartatik (2020), salah satu jurus jitu untuk meningkatkan sistem imun adalah dengan pola makan yang baik. Dalam ilmu pangan, ada istilah yaitu pangan fungsional. Makanan atau minuman yang termasuk dalam kategori pangan fungsional ini dapat diperoleh di sekitar kita dan harganya sangat terjangkau alias murah meriah.

Pangan fungsional adalah makanan/minuman yang tidak hanya sekedar mencukupi kebutuhan akan nutrisi saja namun juga dapat memberikan dampak terhadap kesehatan tubuh. Pangan fungsional ini adalah makanan/minuman yang mengandung antioksidan, berserat tinggi, probiotik, prebiotik, dan sinbiotik, makanan/minuman yang mengandung asam lemak tidak jenuh, bahan pangan yang mengandung senyawa bioaktif, bahan pangan berbasis susu, biji-bijian utuh, serta umbi-umbian. Beberapa jenis bahan pangan ini bahkan bisa ditanam sendiri. 
Menurut Sukendra (2015), aktivitas olahraga yang dapat meningkatkan imun tubuh atau kesegaran jasmani adalah olahraga yang cukup memberikan beban kepada jantung dan paru. Aktivitas latihan fisik ringan lebih bermanfaat pada fungsi imunitas bila dibanding hanya melakukan aktivitas berupa duduk/tidak melakukan kegiatan apapun. Kekebalan tubuh dapat mudah ditingkatkan dengan melakukan latihan fisik/olahraga juga istirahat serta tidur cukup. Mekanisme kenaikan atau penurunan imun saat latihan fisik/olahraga dapat memberikan manfaat positif bagi kesehatan dalam jangka panjang, hal ini berkaitan dengan pertahanan tubuh terhadap infeksi penyakit.

Ibu-Ibu sebagai garda terdepan dalam keluarganya senantiasa menambah wawasan pengetahuannya dengan mencari informasi dan meningkatkan pengetahuannya. Mereka haus akan pengetahuan khususnya dalam menghadapi pandemi Covid-19 saat ini. Ibu-Ibu sangat antusias untuk meningkatkan pengetahuan agar mereka lebih siap dalam menghadapi pandemi covid-19 ini dan dapat memberikan kontribusi dan pengaruh pada gaya hidupp keluarga mereka untuk hidup dengan sehat di masa pandemi Covid-19. Pandemi yang masih berlangsung dan belum bisa dipastikan kapan berakhirnya ini serta masih belum adanya obat dan vaksin yang efektif ini, mengharuskan kita untuk menjaga imunitas tubuh untuk tetap kuat yaitu dengan menerapkan pola makan yang baik dan sehat guna menjaga kebugaran tubuh serta meningkatkan imunitas tubuh (Mustofa \& Suhartatik, 2020).

Pendidikan yang dijalani seseorang memiliki pengaruh pada peningkatan kemampuan berpikir, dengan kata lain seseorang yang berpendidikan lebih tinggi akan dapat mengambil keputusan yang lebih rasional, umumnya terbuka untuk menerima perubahan atau hal baru dibandingkan dengan individu yang berpendidikan rendah (Edison, 2019). Tingkat Pendidikan ibu-ibu kelompok senam di dusun Salakan sebagian besar masih rendah yaitu sebagian besar memiliki latar belakang pendidikan menengah, tetapi Ibu-ibu kelompok senam Salakan ini memiliki motivasi yang tinggi untuk meningkatkan pengetahuan tentang peningkatan sistem imun keluarga dan aktivitas fisik di masa pandemi Covid-19, terbukti dari banyaknya yang hadir pada waktu diadakan pertemuan secara luring dan antusiasme ibu-ibu dengan banyaknya pertanyaan yang diberikan seputar peningkatan daya tahan tubuh keluarga dan aktivitas fisik selama pandemi Covid-19.

Kegiatan pengabdian masyarakat ini sangat bermanfaat untuk menambah bekal pengetahuan dan meningkatkan daya tahan tubuh keluarga sehingga imunitasnya meningkat, aktivitas fisik bisa tetap dijalankan tanpa terkendala kondisi pandemi Covid19. Perlu ditingkatkan lagi tingkat pengetahuan Ibu-Ibu dalam menjalankan protokol Kesehatan di masa pandemi Covid-19 ini dari berbagai aspek di bidang kesehatan.

\section{KESIMPULAN DAN SARAN}

Disimpulkan bahwa Ibu-ibu kelompok Senam setelah diberikan sosialisasi tentang system imun di era pandemi Covid-19 dan aktivitas fisik di era pandemi Covid-19 mengalami peningkatan pengetahuan tentang bagaimana meningkatkan system imun dan aktivitas fisik apa yang baik dilakukan di masa paandemi Covid-19.

Antusiasme Ibu-Ibu peserta abdimas ini perlu diapresiasi dengan dilakukannya pembinaan yang berkelanjutan terkait pengetahuan Ibu-ibu dalam permasalahan Kesehatan pada umumnya. 
7. UCAPAN TERIMA KASIH

LP3M UMY yang telah mendanai kegiatan pengabdian masyarakat ini.

\section{DAFTAR PUSTAKA}

Adhi, I.S. (2020). 10 Cara Meningkatkan Daya Tahan Yubuh. Kompas.com 25 April 2020 diakses dari https://health.kompas.com/read/2020/04/25/193100668/10-carameningkatkan-daya-tahan-tubuh?page=all

Crosbie, T. and Moore, J. (2004). Work-life balance and working from home. Social Policy. (n.d.).

Departemen Kesehatan RI. 2009. Kategori Usia. Dalam http://kategori-umurmenurutDepkes.html. Diakses pada tanggal 1 Februari 2021

Bappenas. (2021). Studi Komparasi Pembelajaran Penanganan Covid-19 IndonesiaKorea Selatan. Direktorat Kesehatan dan Gizi Masyarakat Kementerian Perencanaan Pembangunan Nasional/Badan Perencanaan Pembangunan Nasional

Edison, E. (2019). Hubungan Tingkat Pendidikan dengan Kejadian Anemia pada Ibu Hamil. Jurnal JKFT; 4 (2): 65-71

Handayani, D., Hadi, D.R., Isbaniah, F., Burhan, E., Agustin, H. (2020). Penyakit Virus Corona 2019. Jurnal Respirologi Indonesia, Vol 40 (2): 119-129

Hyoscyamina, D.E. (2011). Peran Keluarga dalam Membangun Karakter Anak. Jurnal Psikologi Undip Vol. 10, No.2, Oktober 2011

Kardini, N.L. (2020). Peranan Perempuan dalam Meningkatkan Pendapatan Keluarga di Desa Pinggan Kintamani. Jurnal Sewaka Bhakti; Volume 4, Nomor 1: 21-35

Kemenkes. (2020). Panduan gizi seimbang pada masa pandemi covid-19. Kemenkes.

Kemenkes RI. (2020). Pedoman Pencegahan Covid-19 di Masyarakat. http://promkes.kemkes.go.id/.

Kemenkes RI. (2020). Pedoman Pencegahan dan Pengendalian Coronavirus Disease (Covid-19). http://promkes.kemkes.go.id/. di akses pada tanggal 20 Mei 2020 jam 10.00 WITA

Makiyah SNNM. 2021. Dasar-Dasar Sistem Imun. Sistem Imun Alamiah dan Sistem Imun Spesifik. Edisi I. LP3M UMY. Yogyakarta.

Mustofa, A., dan Suhartatik, N. (2020). Meningkatkan Imunitas Tubuh Dalam Menghadapi Pandemi Covid-19 di Karangtaruna Kedunggupit, Sidoharjo, Wonogiri, Jawa Tengah. Selaparang: Jurnal Pengabdian Masyarakat Berkemajuan, 4 (1): 324-332 
Nieman, D. C., \& Wentz, L. M. (2019). The compelling link between physical activity and the body's defense system. Journal of Sport and Health Science. 8(3):201-217 doi:10.1016/j.jshs.2018.09.009

Perhimpunan Dokter Paru Indonesia (PDPI), (2020). Panduan Praktik Klinis: Pneumonia 2019-nCov-19 PDPI: Jakarta

Pudjiwati, S. (1993). Peranan Wanita dan Pembangunan Masyarakat Desa. Jakarta: Kanisius.

SK Gubernur No. 340/KEP/2020 pada 18 November 2020 tentang UMR Sleman tahun 2021

Sukendra, DM. (2015). Efek Olahraga Ringan pada Fungsi Imunitas terhadap Mikroba Patogen: Infeksi Virus Dengue. Sport Science Journal; 5 (2): 57-65

WHO. (2020). Coronavirus. https://www.who.int/health- topics/coronavirus\#tab=tab_3

Yuliana. (2020). Corona Virus Diseases (Covid-19); Sebuah Tinjauan Literatur. Wellness and Healthy Magazine, 1(1): 187-192

Zahrok, S. dan Suarmini, N.W. (2018). Peran Perempuan dalam Keluarga. Prosiding SEMATEKSOS 3"Strategi Pembangunan Nasional Menghadapi Revolusi Industri 4.0" Institut Teknologi Surabaya. 14 September 2018. 